\title{
A Study on the Discourse System of Student Management in Private Colleges and Universities
}

\author{
Li Henan \\ Guangdong University of Science \& Technology, Dongguan 523000,China; \\ 38121300@qq.com
}

Key words: discourse system; college student management; feature; construction

\begin{abstract}
At the end of 2016, General Secretary Xi Jinping stressed at the national ideological and political work conference of colleges and universities that the ideological and political work should be carried out through the whole process of education and teaching, and create a new situation in the development of higher education in China. With the further deepening of higher education reform, the social diversification under the Internet, the development of new media and the enhancement of the students' subjective consciousness have brought great changes in the management right and the right to speak to the management of college students. This change is the opportunity for college students to manage, but also to promote the whole job is facing great challenges. We need to study the new features of Internet management under the Internet and the students, and actively explore the new ideas and new ways to construct the discourse system of the students under the Internet.
\end{abstract}

\section{Introduction}

90 years of the 20th century is the cause of private education in China started. Into the 21st century, China's rapid development of private education. On November 7, 2016, the Twenty-fourth Meeting of the Standing Committee of the Twelfth National People's Congress passed the decision on amending the Law on Promotion of Private Education. The bill will be formally implemented on September 1, 2017. The bill is called "the private education from the 'gray zone' to the sun transparent," 2017 Sohu education hot 20 asked, the implementation of private education management, private education to promote the law, once again private education, especially private higher education Pushed to the cusp. There are many voices in the network to question the management of private colleges and universities, such as the role of ideological and political education in private colleges and universities, whether students have the right to speak in school management. In fact, the study of the discourse system of students' management in private colleges is a question of advancing with the times.

\section{The background of private college students management}

Student management is a school social practice that uses discourse to achieve the purpose of management, and has its unique discourse system. As an important part of higher education, private colleges and universities are paid more and more attention. The special discourse system formed under the flexible and autonomous school management mechanism not only provides some reference for the research and innovation of school management, but also exposes some problems. First, part of the private college students management is too dogmatic, leading to management, the right to education "desalination" or "aphasia" crisis; separation of bureaucratic management system, ignoring the students the right to speak, they travel in the school field Outside, at the edge of school power. Second, managers and managers are not dialogue with each other, managers control the right to speak, resulting in its high above, it is difficult from the actual situation of students; managers in the practice of education management by the right to speak, Conduct contact and dialogue with experience alone. Thirdly, the lack of dialogue in the management of private college students, the 
lack of dialogue platform, the lack of dialogue channels, the development of discourse system is one of the characteristics of private college students management. Thus, private college students management discourse system has its own characteristics and problems, this unique discourse system also makes private college student management there is a certain predicament.

\section{The private college students management discourse system characteristics}

Under the Internet age, the rise and popularization of new media, in fact, is permeated with social life and culture, the widespread popularity of the Internet, the continuous development of information technology led to the evolution of the times, led the new social relations, changes in ways of thinking, Also led to the original school management discourse system was broken.

3.1Internet + background of the new media "anti-authoritative" to dilute the authority of traditional student management.

In the traditional student management discourse system, the educational manager is the originator of the discourse content, in the center of the discourse system, has always been the absolute "authority" in the process of discourse communication; and the student is the educator, Passive status, which is the traditional student management discourse system. However, in the new media era, everyone has the right to equal access to information and express themselves, and most students from the media for student management "politics" is quite influential, and even broke the original traditional media age Discourse system, more and more educated, the manager has become the influence of the discourse system. Personalized new media also makes the majority of students thinking mode, behavior patterns have undergone tremendous changes, they pursue themselves, the courage to innovate, hope through free, equal dialogue to express their own life for the entire campus management. This is the first feature of the Internet + .

3.2 The Internet under the education of the market led to the decline of the traditional administrative discourse.

With the deepening of China's higher education reform, the diversification of educational types, colleges and universities have not only the place of education, but also investment components. Education has become an industry in the quiet start of its market-oriented process. And this marketization also makes the students have a new understanding of the relationship between teachers and students: education managers and students are equal to both sides, is equal; the relationship between the two sides is the relationship between service and service, no longer management and Managed relationship. In other words, the marketization of colleges and universities to promote the provision of educational services, students pay to school, colleges and universities to improve the corresponding services, then the service carrier provided by the level of management, students as a service are involved in the right. This is also the Internet under the education market led to the decline of the traditional administrative discourse right.

3.3The Internet + education managers under the role of their own conflict is the original student management discourse system to break the relationship.

In 2004, the Opinions of the CPC Central Committee and the State Council on Further Strengthening and Improving the Ideological and Political Education of College Students pointed out that counselors were an important part of the university teachers' ranks and the backbone of ideological and political education of college students. Because, counselors first is an educator, is mainly responsible for student ideological and political education, but also a manager, responsible for the daily affairs of students management. In the form of education, the main education in the student group building, daily education management, situation and policy education and guidance of the second classroom activities. In ideological and political education, counselors are required to take the main body status, effective education, to guide students to grow. However, the object of education is personality, thought of the student groups and individuals, counselors to respect the student's subjectivity. The reality is that students often expect counselors to be a serviceer who can help them when they have practical difficulties in their lives; they can help them to distract when they are emotionally confused; when they are mentally challenged, Can help them to ease. This requires the counselor to have both the consciousness of the educator, but also the manager's shelf, 
the manager and the intimate situation of the conflict.

\section{Under the college students management discourse system construction}

4.1To strengthen the content construction, to build college students management discourse positions

The construction of the discourse system of student management in colleges and universities must find a fit point for college students. The new discourse system must be a kind of content to adapt to college students, students are loved, should not be the traditional education management in the one-way inculcation of educational content. In the choice of content to fully respect the views of both sides, students can fully express their own reasonable ideas. Education managers and students are equal, the information should also be symmetrical. Content to fully reflect the modern students for the student management system construction expectations. New media era, requires the construction of discourse content to keep up with the times, to be inclusive, to refine the integration, but also close to reality, easy to understand. In this way, for the dissemination of truth, solution doubts, cohesion consensus will work, and truly play the role of energy transmission and guidance. 、

4.2Adhere to the people-oriented, innovative college students management discourse form

With the people-oriented educational management concept fully established, will inevitably bring a new understanding of the educated. Fully respect and play the main role of education and subjective initiative, respect for the educational management of the object of the law of development, pay attention to the management of educational management of the receiving mechanism and accept the effect of these new knowledge will inevitably require the traditional discourse right to change or adjust accordingly, Requirements from the past management model to democratic management, scientific management changes. To dilute the right consciousness, to enhance the equal atmosphere, to ensure that the main body of education management in the discourse system of equality.

4.3Adhere to open and inclusive, and optimize the management of college students discourse channels

The management of college students must grasp the ideological characteristics of young students, innovate their ideas and optimize the channels of management. The pluralistic society must be embodied in the diversification of the expression of people's words. Based on the principle of openness and inclusiveness, it is necessary to grasp the ideological and psychological characteristics of young students in the construction of new discourse power, to create a relaxed discourse context, to make each student equal, Fully express self-will, to innovate the form and way of education management and guide students to express their opinions in a healthy and orderly way; to establish an effective communication mechanism of discourse communication, to achieve unified thinking and eliminate barriers through educational exchange between educational administrators and students , To resolve the purpose of conflict.

4.4Adhere to scientific management, purification of college students management discourse environment

With the advent of the information age, college students manage the discourse system of media means and means of transformation is self-evident. How to create a good network communication environment, to build a good atmosphere of public opinion; how to do a good job of student management guide and how to do a good job in the development of a network of students, Network public opinion control these are the requirements of the university students to manage the discourse environment. Adhere to scientific management, openness of network communication discourse, anonymous attention, pay attention to marginalization and inhibit non-mainstream public opinion, make a moderate response to various mixed network communication discourse, and strive for the discourse audience to understand the propaganda discourse as soon as possible. trust.

\section{References}

[1]Journal of East China Normal University, 2003 (03) [2] Li Jiacheng. Reflections on the Trend of 
School Management Reform in Contemporary China. Educational Theory and Practice, 2004 (24) [2] Wei Zhichun. On the checks and balances of school management power. Modern Education Series, 2000 (01)

[3] Cheng Jin-hong. The basic trend of school management reform in the global perspective. Educational Science Research, 2010 (05)

[4] Lvyuan. Discourse analysis - pioneering management of new horizons. Management of the world, 2012 (10)

[5] Ma Weina. Discourse reproduction and discourse regeneration in school field. Education Review, 2002 (04) 